\title{
The Effect of Arginine Vasotocin and Prostaglandins on Oviposition in the Domestic Fowl (Gallus domesticus)
}

\author{
K. Goto, Y. Nakanishi and K. Ogawa \\ Laboratory of Animal Reproduction, Department of Animal Sciences, \\ Faculty of Agriculture, Kagoshima University, Kagoshima, 890 Japan
}

\section{Introduction}

The oviposition in birds and the parturition in mammals appear to be similar phenomena although the underlying fundamental mechanisms are not fully understood. Since the highproducing domestic hen lays an egg almost daily, it is a convenient animal for the study of such mechanisms.

Arginine vasotocin (AVT) and prostaglandins (PGs) are reported to be concerned in the mechanism of oviposition in hens. TANAKA et al. ${ }^{1,2)}$ reported a decrease in the AVT content of the neurohypophysis which coincided with oviposition. Douglas et al. ${ }^{3}$ and STURKIE et al. 4.5) measured AVT in the blood of laying hens and found that the activity of the hormone increased during oviposition. This was later confirmed by Niezgoda et al. ${ }^{6)}$ Nakada et al. ${ }^{7)}$ reported that a surge in AVT occurred before ovulation of the first egg $\left(\mathrm{C}_{1}\right)$ of a clutch; later TANAKA et al. ${ }^{8)}$ demonstrated that the circulating hormone reached a peak 55 min before $\mathrm{C}_{1}$ ovulation. Recently, TANAKA et al. ${ }^{9}{ }^{9}$ reported that immunoreactive AVT in the plasma of hens increased 5-6 min before oviposition, reached a peak during oviposition and decreased rapidly in the following 5-6 min. The surge in plasma AVT occurred at $48 \mathrm{~min}$ before $\mathrm{C}_{1}$ ovulation.

It has been demonstrated that several PGs, particularly the E series, when injected directly into the hen uterus can induce premature oviposition ${ }^{10)}$. Several additional lines of evidence indicate that certain PGs play a functional role in the regulation of oviposition ${ }^{11,12}$, 13.14). Administration of inhibitors of PG synthesis blocks the premature, as well as spontaneous, oviposition ${ }^{15,16)}$ and inhibits the response to vasotocin which has been implicated in the regulation of oviposition ${ }^{2}$.

The shell gland contractility displays an increasing sensitivity to $\mathrm{AVT}^{17,18)}$ and $\mathrm{PGE}_{\mathbf{1}}{ }^{19)}$ as the time of expected oviposition approaches. An increase in the concentration of PGs in the hen uterus before oviposition has also been demonstrated ${ }^{20)}$. Hertelendy ${ }^{15)}$ and RzASA ${ }^{20)}$ suggested that the uterine-stimulating activity of neurohypophysial peptides might be mediated through uterine PGs. Recently, $\mathrm{RzASA}^{21)}$ reported that uterine homogenate from laying hens not only produced PG but also responded to AVT stimulation by an increase in PG synthesis based on the bioassay determination.

The present study was conducted to examine the effect of $\mathrm{AVT}, \mathrm{PGE}_{2}$ and $\mathrm{PGF}_{2 \alpha}$ on oviposition of hens. In addition the effect of indomethacin, an inhibitor of PG synthesis, on AVT-induced premature oviposition and the effect of AVT on immunoreactive $\mathrm{PGE}_{2}$ pro- 
duction in the uterine homogenate of hens in vitro were examined.

\section{Materials and Methods}

Materials. Prostaglandin $\mathrm{F}_{2 \alpha}$ THAM salt (Pronalgon F, No. 327-7) was kindly supplied from Takeda Chemical Co. (Tokyo, Japan). PGE 2 (No. p-5640) and AVT (No. V-4252) were obtained from Sigma Chemical Co. (St Louis, Missouri, U.S.A.).

Indomethacin (PEP 7180) was from Wako Pure Chemical Industries, Ltd. (Tokyo, Japan).

$\mathrm{PGE}_{2}$ solution $(1 \mathrm{mg} / \mathrm{ml})$ was prepared in $95 \%$ ethanol and kept in the freezer; dilutions were made in $0.9 \% \mathrm{NaCl}$ immediately before use. Solution of $\mathrm{PGF}_{2 \alpha}$ THAM salt (5 mg/ $\mathrm{ml}$ ) was diluted with $0.9 \% \mathrm{NaCl}$. AVT was dissolved in $0.9 \% \mathrm{NaCl}$ shortly before use. Indomethacin was suspended in sesame oil.

Animals. White Leghorn hens which had regular clutches of 5 and 6 consecutive eggs were used. The birds were kept in individual cages, were exposed to $14 \mathrm{~h}$ light/ $24 \mathrm{~h}$ and provided food and water ad libitum.

Experiments 1 and 2. Experiments were carried out to test the effects of AVT, PGE 2 and $\mathrm{PGF}_{2 \alpha}$, injected intravenously, on oviposition of the mid-clutch egg of hens. In experiment 1 , the drugs were injected at 1-4 (hard-shell egg in uterus) or 15-19 h (soft-shell egg in uterus) before the expected time of oviposition. In experiment 2, AVT or saline $(0.9 \%)$ was injected 1, 3, 6 or $9 \mathrm{~h}$ after the intramuscular injection of indomethacin $(50 \mathrm{mg} / \mathrm{bird})$. Indomethacin had been injected at $2-3 \mathrm{~h}$ before the expected time of oviposition. Before the start of Experiment 2, we confirmed that the intramuscular injection of sesame oil $(1 \mathrm{ml} /$ bird) has no effect on normal laying of egg in the hen. The response of the hen was regarded as positive when oviposition was induced within $15 \mathrm{~min}$ after the injection of $\mathrm{PGE}_{2}$, $\mathrm{PGF}_{2 \alpha}$ or AVT. All of the drugs used in the experiments 1 and 2 were injected at the volume of $1 \mathrm{ml}$.

Experiment 3. The effect of AVT on $\mathrm{PGE}_{2}$ production in the uterine homogenates of hens was examined in vitro. Ten hens were killed at $1.5 \mathrm{~h}$ after the oviposition of mid-clutch eggs. The uterus (10 mg) of each hens was removed and homogenized in $20 \mathrm{~m} l$ of TCM 199 at $\mathrm{O}^{\circ} \mathrm{C}$. One $\mathrm{ml}$ aliquots of the uterine homogenate either alone or with AVT $(0.1$ or $1.0 \mu \mathrm{g} / \mathrm{ml}), 50 \mu \mathrm{g} / \mathrm{ml}$ indomethacin, or a combination of these compounds were incubated at $41{ }^{\circ} \mathrm{C}$ for $90 \mathrm{~min}$ under a humidified atmosphere of $95 \% \mathrm{O}_{2}$ and $5 \% \mathrm{CO}_{2}$. After the end of incubation, the tubes containing uterine homogenate were centrifuged at $2000 \mathrm{~g}$ for 30 $\min$ at $4^{\circ} \mathrm{C}$ and the supernatants were used for the extraction of PGs.

Extraction. The supernatant of the uterine homogenate was acidified to $\mathrm{pH} 3.5$ by the addition of $0.1 \mathrm{~N} \mathrm{HCl}$. Small column packed with octadecasilyl silica $\left(\mathrm{C}_{18} \mathrm{SEP}-\mathrm{PAK}\right.$, Water's Associates, Milford, MA) was used to extract PGs from the supernatant. The column was attached to a plastic syringe and washed with $2 \mathrm{~m} l$ of methanol, followed by $2 \mathrm{~m} l$ of deionized water. The acidified supernatant was then applied to the column under a slight positive pressure in which the flow rate is less than $1 \mathrm{ml} / 3 \mathrm{~min}$. The column was washed with 1 $\mathrm{ml}$ of deionized water. The column was then eluted with $1 \mathrm{ml}$ of methanol and the elute was collected in polypropylene tube. The collected elute was dried at room temperature with gentle stream of $\mathrm{N}_{2}$ gas. The recovery of labeled $\mathrm{PGE}_{2}$ was $96 \%$ in this procedure. 
Radioimmunossay. (RIA). Prostaglandin $E_{2}$, ${ }^{125}$ I-RIA kit (NEK-020) was obtained from New England Nuclear Company (Boston, MA). The solution of $\mathrm{PGE}_{2}(100 \mathrm{ng} / \mathrm{ml}$ ) in organic solvent (acetonitrile: $\mathrm{H}_{2} \mathrm{O}=9: 1, \mathrm{pH}$ 5.0) was diluted immediately before use by assay buffer. $\mathrm{PGE}_{2}$ standards consist of $0.1-25 \mathrm{pg} /$ tube. The assay buffer consists of $0.9 \% \mathrm{NaCl}$, $0.01 \mathrm{M}$ EDTA, $0.3 \%$ bovine $\gamma$-globulin (Fr. II), $0.005 \%$ Triton X-100 and $0.05 \%$ sodium azide in $50 \mathrm{mM}$ phosphate buffer, $\mathrm{pH}$ 6.8.

The specific activity of ${ }^{125} \mathrm{I}$-labeled $\mathrm{PGE}_{2}$ was $2200 \mathrm{Ci} / \mathrm{mmol}$.

The extracted and dried sample was reconstituted with an appropriate volume of the assay buffer. Duplicate $100 \mu l$ aliquots of appropriate standards and samples were incubated at $4^{\circ} \mathrm{C}$ in borosilicate RIA tubes with $100 \mu l$ of antiserum and $100 \mu l$ of labeled PGE (15000 $_{2}$ $\mathrm{cpm}$ ) for $24 \mathrm{~h}$. Free and bound hormones were separated by adding $1 \mathrm{ml}$ of precipitating solution (16\% polyethylene glycol 6000 and $0.05 \%$ sodium azide in $50 \mathrm{mM}$ phosphate buffer, $\mathrm{pH}$ 6.8). After centrifugation at $1000 \mathrm{~g}$ for $30 \mathrm{~min}$, precipitate was counted on an autogamma counting system (Packard Model $800 \mathrm{C}$ ).

Cross reaction of the $\mathrm{PGE}_{2}$ antiserum with other compounds was as follows: $\mathrm{PGE}_{1}$, $3.7 \% ; 1314$ Dihydro-15-keto-PGE $2,0.4 \% ; \mathrm{PGA}_{2}, 0.4 \% ; \mathrm{PGF}_{1} \alpha, 0.03 \%$; Thromboxane $\mathrm{B}_{2}, \quad 0.02 \%$ and exhibits less than $0.01 \%$ cross-reactivity with a number of other prostaglandins including $\mathrm{PGF}_{2 \alpha}$.

Intraassay coefficient of variation was $8.0 \% \quad(\mathrm{~N}=5)$. The minimum detectable does defined as the mass corresponding to twice the standard deviation of the zero binding, the sensitivity of the system was $0.1 \mathrm{pg} /$ tube. Uterine $\mathrm{PGE}_{2}$ values were not corrected for recovery.

Statistical analysis. The data were analyzed by ANOVA using the procedure outline in SAS statistical package (BARR etal. $\left.{ }^{22}\right)$ ). Means were separated using the Duncan option of the procedure ${ }^{23,24)}$.

\section{Results}

All three drugs (AVT, $\mathrm{PGE}_{2}$ and $\mathrm{PGF}_{2 \alpha}$ ) induced premature oviposition within a few minutes when injected $1-4 \mathrm{~h}$ before the expected laying time (Table 1). AVT $(0.1 \mu \mathrm{g} / \mathrm{bird}$ ) gave $100 \%(8 / 8)$ successful induction. In comparison, $2 \mu \mathrm{g} / \mathrm{bird}$ of $\mathrm{PGE}_{2}$ and $1 \mu \mathrm{g} / \mathrm{bird}$ of $\mathrm{PGF}_{2 \alpha}$ were needed to induce $100 \%$ successful induction. An equal volume of $0.9 \%$ saline $(1 \mathrm{ml})$ was without effect.

AVT $(0.1 \mu \mathrm{g} / \mathrm{bird})$ failed to cause premature oviposition when injection $15-19 \mathrm{~h}$ before the expected laying time (Table 2). AVT $(0.5 \mu \mathrm{g} / \mathrm{bird})$ was needed to cause $80 \%(4 / 5)$ premature oviposition which was five-times greater does of AVT used than that injected 1$4 \mathrm{~h}$ before the expected laying time to cause $100 \%$ premature oviposition. $\mathrm{PGE}_{2}(10 \mu \mathrm{g} / \mathrm{bird})$ and $\mathrm{PGF}_{2 \alpha}(1 \mu \mathrm{g} / \mathrm{bird})$ caused only $25 \%(2 / 8)$ and $40 \%(2 / 5)$ premature oviposition when injected $15-19 \mathrm{~h}$ before the expected laying time, respectively.

The effect of indomethacin pretreatment $(50 \mathrm{mg} / \mathrm{bird})$ at $2-3 \mathrm{~h}$ before the expected laying time on AVT-induced premature oviposition is shown in Table 3. As shown in Table 1 , AVT $(0.1 \mu \mathrm{g} / \mathrm{bird})$ can cause $100 \%$ premature oviposition when injected $1-4 \mathrm{~h}$ before the expected laying time. AVT $(0.1 \mu \mathrm{g} / \mathrm{bird})$ induced $71(5 / 7), 100(6 / 6), 38(5 / 13)$ and $0 \%$ 
Table 1. Induction of oviposition in the hen by i.v. injection of $\mathrm{PGE}_{2}$, $\mathrm{PGF}_{2 \alpha}$ and $\mathrm{AVT}$ (Exp. 1) a

\begin{tabular}{|c|c|c|c|c|}
\hline Drug & $\begin{array}{c}\text { Dose } \\
(\mu \mathrm{g} / \mathrm{bird})\end{array}$ & $\begin{array}{c}\text { No. of } \\
\text { test }\end{array}$ & $\begin{array}{c}\text { No. of } \\
\text { premature } \\
\text { oviposition }^{b}\end{array}$ & $\begin{array}{c}\text { Average } \\
\text { induction } \\
\text { time }(\min )^{c}\end{array}$ \\
\hline \multirow{5}{*}{$\mathrm{PGE}_{2}$} & 0.1 & 3 & 1 & 9.1 \\
\hline & 0.5 & 6 & 1 & 11.6 \\
\hline & 1.0 & 7 & 5 & $6.8 \pm 2.3$ \\
\hline & 2.0 & 4 & 4 & $4.7 \pm 1.3$ \\
\hline & 10.0 & 3 & 3 & $1.7 \pm 0.3$ \\
\hline \multirow{4}{*}{$\mathrm{PGF}_{2 \alpha}$} & 0.2 & 5 & 0 & - \\
\hline & 1.0 & 6 & 6 & $7.8 \pm 4.4$ \\
\hline & 2.0 & 7 & 7 & $2.5 \pm 0.6$ \\
\hline & 20.0 & 4 & 4 & $2.7 \pm 0.9$ \\
\hline \multirow{3}{*}{ AVT } & 0.05 & 5 & 2 & $4.9 \pm 0.8$ \\
\hline & 0.1 & 8 & 8 & $3.2 \pm 0.7$ \\
\hline & 0.5 & 4 & 4 & $2.2 \pm 0.7$ \\
\hline $\begin{array}{l}\text { Saline } \\
(0.9 \%)\end{array}$ & - & 5 & 0 & - \\
\hline
\end{tabular}

a Drug was injected 1-4 h before expected oviposition.

b The response of the hen was regarded as positive when oviposition was induced within $15 \mathrm{~min}$ after injection.

C Values are mean \pm s. d.

Table 2. Induction of oviposition in the hen by i.v. injection of $\mathrm{PGE}_{2}$, $\mathrm{PGF}_{2 \alpha}$ and AVT (Exp. 1) ${ }^{\mathrm{a}}$

\begin{tabular}{ccccc}
\hline Drug & $\begin{array}{c}\text { Dose } \\
(\mu \mathrm{g} / \mathrm{bird})\end{array}$ & $\begin{array}{c}\text { No. of } \\
\text { test }\end{array}$ & $\begin{array}{c}\text { No. of } \\
\text { premature } \\
\text { oviposition }\end{array}$ & $\begin{array}{c}\text { Average } \\
\text { induction } \\
\text { time }(\mathrm{min})^{\mathrm{c}}\end{array}$ \\
\hline $\mathrm{PGE}_{2}$ & 2.0 & 3 & 0 & - \\
\hline & 5.0 & 3 & 0 & - \\
$\mathrm{PGF}_{2 \alpha}$ & 10.0 & 5 & 2 & $5.5 \pm 1.0$ \\
\hline AVT & 1.0 & 6 & 2 & $5.5 \pm 1.4$ \\
\hline Saline & 10.0 & 7 & 4 & $3.1 \pm 0.4$ \\
\hline$(0.9 \%)$ & 0.1 & 5 & 4 & $2.5 \pm 0.6$ \\
\hline
\end{tabular}

a Drug was injected 15-19 h before expected oviposition.

b The response of the hen was regarded as positive when oviposition was induced within $15 \mathrm{~min}$ after injection.

c Values are mean \pm s. d.

$(0 / 8)$ premature oviposition when injected at $1,3,6$ and $9 \mathrm{~h}$ after indomethacin treatment, respectively. AVT $(0.5 \mu \mathrm{g} / \mathrm{bird})$ induced $67(4 / 6), 67(4 / 6)$ and $78 \%(7 / 9)$ premature oviposition when injected at 1,6 , and $9 \mathrm{~h}$ after indomethacin treatment, respectively. An equal volume of saline $(0.9 \% \mathrm{NaCl})$ was without effect. All hens which failed to cause 
Table 3. Induction of oviposition in the hen by i.v. injection of AVT following to i.m. injection of indomethacin (Exp. 2) ${ }^{a}$

\begin{tabular}{|c|c|c|c|c|c|c|c|}
\hline $\begin{array}{l}\text { Time after } \\
\text { injection of } \\
\text { indomethacin }\end{array}$ & Drug & $\begin{array}{c}\text { Dose } \\
(\mu \mathrm{g} / \mathrm{bird})\end{array}$ & $\begin{array}{l}\text { No. of } \\
\text { test }\end{array}$ & $\begin{array}{c}\text { No. of } \\
\text { premature } \\
\text { oviposition }^{b}\end{array}$ & $\begin{array}{c}\text { No. of } \\
\text { delayed } \\
\text { oviposition }\end{array}$ & $\begin{array}{c}\text { Average } \\
\text { induction } \\
\text { time }(\min )^{c}\end{array}$ & $\begin{array}{c}\text { Delayed } \\
\text { oviposition } \\
\text { (h) }\end{array}$ \\
\hline 1 & AVT & 0.1 & 7 & 5 & 2 & $3.1 \pm 0.5$ & $14 \cdot 23$ \\
\hline 1 & AVT & 0.5 & 6 & 4 & 2 & $1.7 \pm 0.4$ & $15-23$ \\
\hline 3 & AVT & 0.1 & 6 & 6 & 0 & 4. $0 \pm 1.4$ & - \\
\hline 3 & AVT & 0.5 & - & - & - & - & - \\
\hline 6 & AVT & 0.1 & 13 & 5 & 8 & $5.0 \pm 0.6$ & $12-21$ \\
\hline 6 & AVT & 0.5 & 6 & 4 & 2 & $3.5 \pm 1.5$ & $13-22$ \\
\hline 9 & AVT & 0.1 & 8 & 0 & 8 & -- & $11-23$ \\
\hline 9 & $\mathrm{AVT}$ & 0.5 & 9 & 7 & 2 & 4. $1 \pm 0.8$ & $21-22$ \\
\hline 1 & $\begin{array}{l}\text { Saline } \\
(0.9 \%)\end{array}$ & - & 8 & 0 & 8 & - & $12-20$ \\
\hline 3 & $\begin{array}{l}\text { Saline } \\
(0.9 \%)\end{array}$ & - & 8 & 0 & 8 & - & $12-20$ \\
\hline 6 & $\begin{array}{l}\text { Saline } \\
(0.9 \%)\end{array}$ & - & 5 & 0 & 5 & - & $13-23$ \\
\hline 9 & $\begin{array}{l}\text { Saline } \\
(0.9 \%)\end{array}$ & - & 5 & 0 & 5 & - & $12-23$ \\
\hline
\end{tabular}

a Indomethacin (50 mg/bird) was injected intramuscularlly $2-3 \mathrm{~h}$ before expected oviposition.

b The response of the hen was regarded as positive when oviposition was induced within 15 min after the injection of AVT.

c Values are mean \pm s. d.

Table 4. Effects of AVT and indomethacin(IND) on immunoreactive $\mathrm{PGE}_{2}$ production in uterine homogenate of hens(exp. 3)

\begin{tabular}{lcc}
\hline Treatment & $\mathrm{n}$ & $\begin{array}{c}\text { Production of } \mathrm{PGE}_{2} / 90 \mathrm{~min} \\
(\mathrm{ng} / \mathrm{g} \text { wet wt) }\end{array}$ \\
\hline Control & 10 & $108 \pm 16^{\mathrm{c}}$ \\
$\operatorname{AVT}(0.1 \mu \mathrm{g} / \mathrm{ml})$ & 10 & $151 \pm 23^{\mathrm{b}}$ \\
$\operatorname{AVT}(0.1 \mu \mathrm{g} / \mathrm{ml})$ & 10 & $57 \pm 8^{\mathrm{d}}$ \\
$+\mathrm{IND}(50 \mu \mathrm{g} / \mathrm{ml})$ & 10 & $52 \pm 8^{\mathrm{d}}$ \\
$\operatorname{IND}(50 \mu \mathrm{g} / \mathrm{ml})$ & 5 & $182 \pm 20^{\mathrm{a}}$ \\
$\operatorname{AVT}(1.0 \mu \mathrm{g} / \mathrm{ml})$ & 5 & $62 \pm 4^{\mathrm{d}}$ \\
$\operatorname{AVT}(1.0 \mu \mathrm{g} / \mathrm{ml})$ & & \\
$+\mathrm{IND}(50 \mu \mathrm{g} / \mathrm{ml})$ & &
\end{tabular}

a Values are mean \pm s. d., Means with different superscripts are significantly different $(P<0.05)$.

premature oviposition layed eggs 11-23 $\mathrm{h}$ after the expected laying time.

Basal- and AVT-stimulated synthesis and the effect of indomethacin on PGE 2 production in the uterine homogenate of hens are shown in Table 4. AVT in the absence of indomethacin stimulated $\mathrm{PGE}_{2}$ production significantly. Both the control $\mathrm{PGE}_{2}$ production and the AVT-stimulated production in the uterine homogenates were suppressed by indomethacin.

\section{Discussion}

The effect of various PGs on the uterus and oviduct both in vivo and in vitro has been studied extensively in animals. Hertelendy ${ }^{15)}$, Hertelendy et al. ${ }^{10)}$ and RzASA ${ }^{20}$ ) examined 
the effects of PGs in the avian species and they induced premature oviposition in the Japanese quail and in the domestic hen by the administration of PGs. The present result of $\mathrm{PGE}_{2}-$ and $\mathrm{PGF}_{2 \alpha}$-induced oviposition agree with those reports.

Several authors demonstrated that the injection of oxytocin, and especially its 8-arginine analog AVT, can induce premature oviposition in hens ${ }^{2,18,20)}$. The present result of the AVT-induced premature oviposition agrees with those reports.

All three drugs ( $\mathrm{PGE}_{2}, \mathrm{PGF}_{2 \alpha}$ and AVT) used in the present study were more effective in inducing oviposition when a hard-shell egg was in the uterus than when a soft-shell egg was in the uterus. This indicates that the sensitivity of the uterus to AVT rises toward the time of normal oviposition ${ }^{18)}$. The similar changes in the sensitivity of the uterus to $\mathrm{PGE}_{2}$ and $\mathrm{PGF}_{2 \alpha}$ were also observed as suggested to $\mathrm{PGE}_{1}{ }^{19)}$.

VANE et $a$. $^{25}$ ) first suggested that the uterine-stimulating activity of the neurohypophyseal hormone, oxytocin, might be mediated through uterine PG. Hertelendy ${ }^{15)}$ showed that oxytocin-induced parturition in the term pregnant rabbits could be blocked by indomethacin, an inhibitor of PG biosynthesis. Oxytocin-induced oviposition in the Japanese quail ${ }^{15}$ and AVT-promoted contractile activity of hen uterine strips ${ }^{20)}$ can also be suppressed with indomethacin. This suggests that endogenous PG production is involved in the uterotonic action of these neurohypophyseal hormone in bird. This was later confirmed by RzASA ${ }^{21)}$ who reported that PG-releasing effect of AVT is not a secondary response to uterine contraction but represents a direct effect of AVT in hens.

The high incidence $(100 \%)$ of exogenous AVT-induced premature oviposition at $3 \mathrm{~h}$ after indomethacin treatment could be due to the increased sensitivity of uterus to AVT since this is the time very close to the expected oviposition. However, even at this time the injection of saline $(0.9 \% \mathrm{NaCl})$ was without effect and the egg was laid $12-20 \mathrm{~h}$ after the expected laying time. This indicates that either the endogenous AVT surge which is known to occur before oviposition ${ }^{3,4,5,6,9)}$ failed to induce $P G$ synthesis due to indomethacin treatment or the surge of AVT was blocked by indomethacin treatment.

AVT $(0.1 \mu \mathrm{g} / \mathrm{bird})$ failed to induce premature oviposition when injected at $9 \mathrm{~h}$ after indomethacin treatment but high does $(0.5 \mu \mathrm{g} / \mathrm{bird})$ of AVT induced $78 \%$ (7/9) premature oviposition. This should be due to the following reasons. (1) AVT-induced PG-synthesis is blocked completely at low dose $(0.1 \mu \mathrm{g} / \mathrm{bird})$ of AVT-injected birds by indomethacin but high does $(0.5 \mu \mathrm{g} / \mathrm{bird})$ of AVT overcomes the block of indomethacin to induce oviposition. (2) The decreased sensitivity of uterus to AVT because this is 6-7 h after the expected laying time.

However, altanative explanation remains that the efficacy of i. m. injection of indomethacin is influenced by the rate of absorption and delivery to the site of action, hence it show ed the ability to block completely the low dose of AVT $(0.1 \mu \mathrm{g} / \mathrm{bird})$ at $9 \mathrm{~h}$ but not at $1-3$ $\mathrm{h}$ after injection.

Our present result would suggest that the sensitivity of hen uterus to AVT, PGE 2 and $\mathrm{PGF}_{2 \alpha}$ increased as the time of oviposition approaches and that the AVT acts through the enhancement of $\mathrm{PGE}_{2}$ production in the hen uterus. However, several questions are remained to be elucidated. Some of them are: (1) Whether or not indomethacin blocks endogenous 
AVT surge under certain condition. (2) Whether or not PGs have a feedback mechanism to neurohypophysis to control AVT release. (3) What is controlling the sensitivity of uterus to AVT and $\mathrm{PG}_{\mathrm{s}}$ ?

TANAKA et $a{ }^{26)}$ reported an ovarian oviposition-inducing factor (OOIF), which causes premature oviposition in the ruptured follicles of hens. Thus, an additional and comprehensive study is needed before the mechanism of oviposition is fully understood.

\section{Summary}

Arginine vasotocin (AVT), prostaglandin $\mathrm{E}_{2}\left(\mathrm{PGE}_{2}\right)$ and prostaglandin $\mathrm{F}_{2 \alpha}\left(\mathrm{PGF}_{2 \alpha}\right)$ induced premature oviposition when injected 1-4 h (hard-shell egg in uterus) and 15-19 h (soft-shell egg in uterus) before the expected laying time.

These drugs were more effective in inducing oviposition when a hard-shell egg was in the uterus than when a soft-shell egg was in the uterus. AVT caused an increase in immunoreactive $\mathrm{PGE}_{2}$ production when incubated with uterine homogenate.

The present results suggest that the sensitivity of the hen uterus to AVT, $\mathrm{PGE}_{2}$ and $\mathrm{PGF}_{2 \alpha}$ increases as the time of oviposition approaches and that AVT acts through the enhan cement of immunoreactive $\mathrm{PGE}_{2}$ production in the uterine tissue of hens.

\section{Acknowledgements}

We thank Mr. Oyama for help with the collection of data. This research was supported by Grant-in-Aid (58360028) from the Ministry of Education, Science and Culture of Japan.

\section{References}

1) Tanaka, K. and S. Nakajo (1960) Oxytocin in the neurohypophysis of the laying hen. Nature, London 187: 245.

2) Tanaka, K. and S. Nakajo (1962) Participation of neuro-hypophysial hormone in oviposition in the hen. Endocrinology 70: 453-458.

3) Douglas, D. S. and P. D. Sturkie (1964) Plasma levels of antidiuretic hormone during oviposition in the hen. Fed. Proc. 23: 150.

4) Sturkie, P. D. and Y. -C. Lin (1966) Release of vasotocin and oviposition in the hen. J. Endocrinol. 35: 325-326.

5) Sturikie, P. D. and Y. -C. Lin (1967) Further studies on oviposition and vasotocin release in the hen. Poultry Sci. 46: 1591-1592.

6) Niezgoda, J., J. Rzasa and Z. Ewy (1973) Changes in blood vasotocin activity during oviposition in the hen. J. Reprod. Fertil. 35: 505-509.

7) NaKada, T. and K. TanaKa (1973) Changes in plasma oviposition-inducing hormone during the laying cycle of the hen. Japan Poult. Sci. (Fall Supp.) 10: 15.

8) Tanaka, K., T. Nakada and O. Koga (1982) Changes in frog-water-balance activity of hen's blood shortly before ovulation of the first egg and during oviposition of terminal egg in the clutch. Japan Poult. Sci. 19: 124-125.

9) Tanaka, K., K. Goto, T. Yoshioka, T. Terao and O. Koga (1984) Changes in the plasma concentration of immunoreactive arginine vasotocin during oviposition in the domestic fowl. British Poultry Sci. 25: 589-595.

10) Hertelendy, F., M. Yeh and H. V. Biellier (1974) Induction of oviposition in the domestic hen by prostaglandins. Endocrinology 22: 529-531.

11) Hertelendy, F. and H. V. Biellier (1978) Prostaglandin levels in avian blood and reproductive organs. Biol. Reprod. 18: 204-211.

12) Hertelendy, F. and H. V. Biellier (1978) Evidence for a physiological role of prostaglandins in oviposition by the hen. J. Reprod. Fertil. 53: 71-78. 
13) Wechsung, E. and A. Houvenaghel (1976) A possible role of prostaglandins in the regulation of ovum transport and oviposition in the domestic hen. Prostaglandins 12: 599-608.

14) Wechsung, E. and A. Houvenaghel (1978) Effect of prostaglandins on oviduct tone in the domestic hen in vivo. Prostaglandins 15: 491--505.

15) Hertelendy, F. (1973) Block of oxytocin-induced parturition and oviposition by prostaglandin inhibitors. Life Sci. 13: 1581-1589.

16) Day, S. L. and A. V. Nalbandov (1977) Presence of prostaglandin F (PGF) in hen follicles and its physiological role in ovulation and oviposition. Biol. Reprod. 16: 486-494.

17) Gilbert, A. B. and P. E. Lake (1963) The effect of oxytocin and vasopressin in the domestic hen. J. Physiol., London 169: 52-53.

18) Rzasa, J. and Z. EWY (1970) The effect of vasotocin and oxytocin on oviposition in the hen. J. Reprod. Fertil. 21: 549-550.

19) Hertelendy, F., H. V. Biellier and H. Todd (1975) Effects of the egg cycle and route of administration on prostaglandin-induced oviposition of hens and Japanese quail. J. Reprod. Fertil. 44: $579-582$.

20) Rzasa, J. (1978) Effects of arginine vasotocin and prostaglandin $\mathrm{E}_{1}$ on the hen uterus. Prostaglandins 16: $357-372$.

21) Rzasa, J. (1984) The effect of arginine vasotocin on prostaglandin production of the hen uterus. Gen. Comp. Endocrinol. 53: 260-263.

22) Barr, A. J., J. H. Goodnight, J. P. Sall and J. T. Hellwig (1976) A User's Guide to SAS 76. Institute Inc., Raleigh, N. C.

23) Duncan, D. B. (1955) Multiple range and multiple F tests. Biometrics 11: 1-42.

24) Harter, H. L. (1960) Critical values for Duncan's New Multiple Range test. Biometrics 16: 671685.

25) Vane, J. R. and K. I. Williams (1973) The contribution of prostaglandin production to contraction of the isolated uterus of the rat. British J. Pharmacol. 48: 629-639.

26) Tanaka, K. and K. Goto (1976) Partial purification of the ovarian oviposition-inducing factor and estimation of its chemical nature. Poultry Sci. 55: 1774-1778. 


\title{
アルギニン・バゾトシンとプロスタグランジンの
}

鶏の放卵に及ぼす影響

\author{
後藤和文・中西喜彦・小川清彦
}

鹿児島大学㖘学蔀，鹿児島术 890

フルギニン・バゾトシン (AVT) とプロスタグランジ ン (PG) は鶏の放卵機序に関与していることが知られて いるが，AVTとPG の放卯に及ぼす相互関係に関し ての報告は少ない。本研究では, AVT, $\mathrm{PGE}_{2}, \mathrm{PGF}_{2 \alpha}$, の放卵に及ぼす効果，AVTによる誘起放卵に刘するイ ンドメタシン (PG 合成阻害剂) 前処理の効果, ならび に子宮の PG 生合成に及ぼす AVT の効果を in vitro で検討した。

実駼 I では， C s 卵の推足放卵前 1-4 時間の鵴に, 尖験 IIでは， C $\mathrm{s}$ 卵の推定放卵前 15一19 時間の鶏に， AVT, $\mathrm{PGE}_{2}, \mathrm{PGF}_{2 \alpha}$ を静脈内投! j.し，放卵に及放少效 果を調べた。笑駼而では, 推主放卵前 2-3 時間の鷄に インドメタシン $(50 \mathrm{mg} / \mathrm{bird})$ を筋肉入投 $/ \mathrm{j}$ し, そ0後 1，3，6，9 時間目に AVT 老静脈队投 唀起放卵に及ぼすインドメタシンの効果を調べた。尖験 IVでは，放卵後 1.5 時間目に子究を取り出し，TCM 199 を加えてホモゲナイズ後，與菌的に $95 \% \mathrm{O}_{2}, \quad 5 \% \mathrm{CO}_{2}$
下で 1.5 時間培養した。実験区には，AVT，インドメ タシンを単独で, あるいは併用して添加して培養し, 無 添加区を対照区とした。培養後生産された $\mathrm{PGE}_{2}$ 量を RIAにて測定した。

以上の実験より, AVT, $\mathrm{PGE}_{2}, \mathrm{PGF}_{2 \alpha}$ はいら゙れも推 全放卵時刻が近い程, 放卵誘起効果が高いことがわかっ た。インドメタシン前处理（推分放卵前 $2-3$ 時間）は, すべての鶏において放卵を 11-23 時間遅延させ, イン ドメタシン前処理の鵎に AVTを投よj-与ると推迆放卵

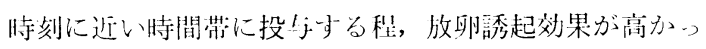

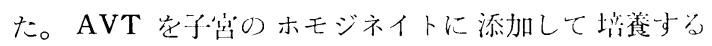
と, $\mathrm{PGE}_{2}$ の生産量が有意に増加した。

以上の絬果より，予行のAVT, $\mathrm{PGE}_{2}, \mathrm{PGF}_{2 \alpha}$ に刘

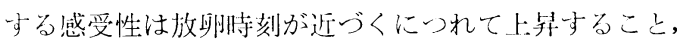
またAVT 法子宫でのPG 生合成を促進与ることによ り放卵に関!゙てしいることが示唆された。

(家去会誌, 22，55６3，1985） 